\title{
ECONOMIC IMPACT OF COUNSELING ON THE MANAGEMENT OF PATIENTS WITH TYPE 2 DIABETES MELLITUS ADMITTED TO A HOSPITAL
}

\author{
YANNA ROTUA SIHOMBING, AZIZAH NASUTION*, ROSIDAH RASYIDIN HARUN
}

\author{
Department of Pharmacology, Faculty of Pharmacy, Universitas Sumatera Utara, Medan, Indonesia. Email: nasution.azizah4@gmail.com
}

Received: 07 March 2018, Revised and Accepted:25 March 2018

ABSTRACT

Objective: The objective of the study was to study the impact of counseling on costs and effectiveness of type 2 diabetes mellitus (T2DM) outpatients in An-Nisa Hospital, Tangerang, Indonesia, period July 2016 to November 2016.

Methods: This 4-month prospective quasi-experimental study was undertaken to analyzed the impact of counseling on cost and effectiveness in the treatment of patients with T2DM ( $\mathrm{n}=30)$. The cost analysis was conducted from the perspective of Badan Penyelenggara Jaminan Sosial abbreviated as BPJS (Social Security Management Agency abbreviated as SSMA). Characteristics of the patients were analyzed using the Chi-Square method. Costeffectiveness was analyzed by calculating cost-effectiveness ratio (CER) and Incremental CER (ICER) in groups with and without counseling.

Results: The study indicated that most (70\%) of the patients were female with ages: $>45,83.3 \%$; $\leq 45,16.7 \%$. It was found that CER in groups: Without counseling, Rp4,111,785; with counseling, Rp582,875. ICER was Rp67,416.

Conclusion: This study proved that counseling improved the outcome on the treatment of patients with T2DM.

Keywords: Type 2 diabetes mellitus, Counseling, Carcinoembryonic antigen.

(C) 2018 The Authors. Published by Innovare Academic Sciences Pvt Ltd. This is an open access article under the CC BY license (http://creativecommons. org/licenses/by/4. 0/) DOI: http://dx.doi.org/10.22159/ajpcr.2018.v11s1.26577

\section{INTRODUCTION}

Diabetes mellitus (DM) is one of the non-contagious diseases with continues increasing prevalence in developed as well as developing countries, including Indonesia. DM caused 1.5 million deaths worldwide in 2012. According to the World Health Organization (WHO), the global prevalence of diabetes has nearly doubled since 1980, rising from $4.7 \%$ to $8.5 \%$ in 2014. Globally, the numbers of DM patients were 422 million adults in 2014, compared to108 million in 1980 [1]. In 2000, the numbers of DM patients in Indonesia were 8.4 million and predicted to reach 21.3 million in 2030 [2].

DM is a metabolic disorder due to the insufficiency of insulin function characterized by high blood glucose levels and followed by carbohydrates, lipids, and proteins metabolism failure. Failure of insulin production by the beta cells of the pancreatic islets or insulin resistance is a cause of insufficiency of insulin function [3]. The advancement of economic development in Indonesia has affected lifestyle and reduced physical activities causing changing in patterns of diseases [4]. In addition, socioeconomic levels including education, employment, and marital status also promote the occurrence of the disease. Such conditions lead to increased prevalence of DM in Indonesia [5].

Patients with type 2 DM (T2DM) who do not know that they suffer from the disease will finally experience complications. Huge losses in both individual and overall health sector can be caused by the T2DM complications. These complications, including catastrophic disease, consumed $33 \%$ of medical costs or approximately Rp3.27 trillion expelled by the SSMA in Indonesia [6].

Health-care providers are required to provide the qualified health care in the globalization era. The current health service often found overlapping on the actions of inter-profession service due to lack of cooperation among health-care providers. Consequently, the patients did not receive optimal treatment [7]. Uncontrolled blood glucose levels in the patients with T2DM are resulted from the non-optimal treatment. This circumstance confers the opportunity for the pharmacists to contribute to the treatment of patients with T2DM [8]. Patient counseling is an inseparable part and a key element of pharmaceutical care, because now the roles of pharmacists not only do compounding and dispensing tasks but also must interact with patients to increase their adherence to the prescribed medications and optimize their treatment outcomes as mentioned in the concept of pharmaceutical care [9].

The efficiency of the resources used and the effectiveness of treatment are the factors need to be considered because a good and appropriate therapy treatment will be very beneficial for the patients, both in terms of health and the recovery from the disease suffered and costs spent [10]. At the past decade, pharmacoeconomics has been widely applied to compare alternative treatments or interventions. Its results are important sources of information needed health-care providers as well as policymakers to optimize health care [11].

This study was performed to compare the cost-effectiveness in the treatment of patients with and without counseling conducted based on the perspective of health-care providers.

\section{METHODS}

This 4-month prospective quasi-experimental study was undertaken to analyze the impact of counseling on cost and effectiveness in the treatment of patients with T2DM $(n=30)$ admitted to An-Nisa hospital Tangerang, Indonesia. The study was conducted from the perspective of SSMA as a health-care provider. Characteristics of the patients were analyzed using Chi-square method. Cost-effectiveness was analyzed by calculating cost-effectiveness ratio (CER) and incremental CER (ICER) in groups with and without counseling.

The research sampling did not use random assignment because researchers must receive a subjects group who met the inclusion criteria [12]. The target population was all T2DM outpatients admitted to An-Nisa hospital, Tangerang, period June to November 2016. The population study was T2DM outpatients using SSMA claim admitted to An-Nisa hospital Tangerang. Exclusion criteria were DM type 1 patients, DM gestational, and anemia diabetic patients. 
Number of the T2DM patients who met the inclusion criteria were 30 patients and used as the subjects in this study. The patients were not given counseling at the $1^{\text {st }} 2$ months of the study called as a group without counseling. In the next 2 months of the study, they were provided counseling at intervals 4 weeks called as group with counseling. The required data were assessed from both groups. These data were the characteristics of the patients including sex, age, and education. The outcome data assessed were hemoglobin $\mathrm{A}_{1 \mathrm{c}}\left(\mathrm{HbA}_{1 \mathrm{c}}\right)$ levels recorded every 2 months. The direct medical costs components assessed were the physician visits, pharmacist counseling costs, the anti-hyperglycemic and other drugs costs.

\section{Data analysis}

The characteristics of the patients were statistically analyzed using Chi-square test. Cost-effectiveness analysis was done using the average CER ratio formula calculated based on total costs used by the T2DM patients toward the treatment effectiveness. The comparison between the treatments of the patients in groups with and without counseling was analyzed using the ICER (Cost $t_{\text {with counseling }}-$ Cost $_{\text {beforecounseling }}$ )/ (Outcome with counseling - Outcome before counseling $_{\text {). }}$.

One-way sensitivity analyzes were implemented to improve the quality and usefulness of carcinoembryonic antigen (CEA). Drug costs were increased to $5 \%, 10 \%$, and $15 \%$. The total of the new costs, costeffectiveness ratio, and ICER were recalculated. All calculations were done using Microsoft Excel and SPSS.

\section{RESULTS}

The characteristics of the T2DM patients based on sex, age, and education are shown in Table 1 . The present study indicated that most $(70 \%)$ of the patients were females. Majority $(83.3 \%)$ of them were at the age over 45 years, while only $16.7 \%$ of them were at the age $\leq 45$ years. The education of the T2DM patients in decreasing order was elementary (36.7\%), junior high school (33.3\%), and senior high school (30\%). Statistical results on the characteristics by sex, age, and education level of the T2DM patients were obtained by consecutive probability scores as total $0.028,<0.001$, and 0.905 .

\section{Cost-effectiveness analysis}

This study was undertaken from the health-care provider's perspective. Thus, the costs included in the analysis were only direct medical costs that consist of the doctor cost, pharmacist counseling cost, and drugs cost. The costs consumed by the T2DM patients in group with

Table 1: Characteristics of the patients with T2DM $(n=30)$

\begin{tabular}{lll}
\hline Variable & Percentage (\%) & p \\
\hline Sex & & 0.028 \\
$\quad$ Male & 30 & \\
$\quad$ Female & 70 & $<0.001$ \\
Age & & \\
$\quad>45$ & 83.3 & \\
$\quad \leq 45$ & 16.7 & 0.905 \\
Education & & \\
$\quad$ Elementary & 36.7 & \\
$\quad$ Junior high school & 33.3 & \\
$\quad$ Seniorhigh school & 30 & \\
\hline T2DM: Type 2 diabetes mellitus & &
\end{tabular}

and without counseling are demonstrated in Table 2. The total direct medical costs per patient in the group with counseling was Rp594,532 with an average reduction of $\mathrm{HbA}_{1 \mathrm{C}}$ is $1.02 \%$. The total direct medical costs per patient in the group without counseling was Rp534,532 with an average reduction of $\mathrm{HbA}_{1 \mathrm{C}}$ is $0.13 \%$.

\section{Sensitivity analysis}

The results of sensitivity analysis are shown in Table 3 . There was no significant difference between the initial CER and CER at an increase of drug costs 5,10 , and $15 \%$ in the groups with and without counseling. Initial ICER score and ICER that has increased drug cost at 5, 10, and $15 \%$ is the same, amounting to Rp67,416.

\section{DISCUSSIONS}

The results of the present study showed that most of the T2DM patients were females with age $>45$ years. Physically, women have greater chance to increase index of body mass, monthly cycle syndrome (premenstrual syndrome), and postmenopause made it easy to accumulate in the body as a result of the hormonal process. Therefore, the prevalence of DM in women is higher than men [13]. American Diabetes Association states that people over 45 years old have more chance to develop the disease [14].

This study indicated that the patients had different levels of education. Similar results were also obtained in a previous study on T2DM risk factors in a primary health center, Jakarta. It was found that there was no correlation between level of education and the occurrence of the T2DM [15]. The patients with high education supposed to have a greater concern for their health. In reality, highly educated people ignore their health for various reasons, one of which is the overloaded works and activities that ultimately lead to unorganized lifestyles and health problems [16].

The treatment in group with counseling was more cost-effective compared to the group without counseling. CER in the group with counseling was Rp582,875, while in the group without counseling was amounted Rp4,111,785. Based on the ICER analysis it was concluded that for every $1 \%$ reduction in $\mathrm{HbA}_{1 \mathrm{c}}$ was required additional cost of Rp67,416. Based on these results, it can be concluded that the costeffectiveness ratio in T2DM patients, when compared with the WHO threshold ratio, was less than gross domestic product (GDP) per capita (GDP per capita=US $\$ 3,346.5$ ), thus, the result of the present study can be considered by policy makers and health-care providers to improve the treatment of patients with T2DM. Treatment of patients with T2DM with counseling is more cost-effective compared with those without counseling. Having conducted a sensitivity analysis, it can be concluded that the results of the CEA can still be used for the next several years in uncertain economic conditions.

Studies on the impact of counseling on the cost-effectiveness in the management of diabetes conducted in Indonesia are still limited. However, many studies proved that counseling and clinical pharmacy education on management of few diseases improved the outcomes and decreased the treatment costs. A quasi-experimental study conducted on patients with chronic kidney disease in an Indonesian hospital indicated that management of the disease with education was more cost-effective compared to those without education [17].

Table 2: Cost-effectiveness analysis in the groups with and without counseling

\begin{tabular}{|c|c|c|}
\hline Description & Without counseling & With counseling \\
\hline Doctor cost & Rp5,400,000 & $\mathrm{Rp5}, 400,000$ \\
\hline Pharmacist counseling & - & Rp1,800,000 \\
\hline Drugs cost & Rp10,635,720 & Rp10,635,720 \\
\hline Direct medical costs & Rp16,035,960 & Rp17,835,960 \\
\hline Total direct medical costs per patient & $\operatorname{Rp} 534,532\left(x_{1}\right)$ & $\operatorname{Rp} 594,532\left(x_{2}\right)$ \\
\hline Outcome (average reduction $\mathrm{HbA}_{1 \mathrm{c}}$ ) (y) & $0.13 \%\left(\mathrm{y}_{1}\right)$ & $1.02 \%\left(\mathrm{y}_{2}\right)$ \\
\hline $\mathrm{CE}$ ratio $=\mathrm{x} / \mathrm{y}$ & Rp4,111,785/reduction $1 \% \mathrm{HbA}_{1 \mathrm{C}}$ & Rp582,875/reduction $1 \% \mathrm{HbA}_{1 \mathrm{C}}$ \\
\hline
\end{tabular}

$\left(\right.$ Costx $\left._{2}-\operatorname{costx}_{1}\right) /\left(\right.$ Treatment effectiveness $y_{2}-$ Treatment effectiveness $\left.y_{1}\right)=$ Rp60,000/0.89\% $=$ Rp67,416. HbA $A_{1 C}:$ Hemoglobin $A_{1 C}$ 
Table 3: Results of the sensitivity analysis

\begin{tabular}{ll}
\hline Description & $\begin{array}{l}\text { Group without counseling } \\
\text { (control group) }\end{array}$ \\
\hline Total direct medical costs per patient after drugs cost & \\
increased (\%) & $\begin{array}{l}\text { Group with counseling } \\
\text { (experimental group) }\end{array}$ \\
5 & $\mathrm{Rp552,250}$ \\
10 & $\mathrm{Rp569,976}$ \\
15 & $\mathrm{Rp} 587,703$ \\
Treatment effectiveness (average reduction HbA1C) (y) & $0.13 \%\left(\mathrm{y}_{1}\right)$ \\
CE ratio=x/y after drugs cost increased (\%) & \\
5 & $\mathrm{Rp} 4,248,078$ \\
10 & $\mathrm{Rp} 4,384,434$ \\
15 & $\mathrm{Rp} 4,520,789$ \\
ICER after drugs cost increased (\%) & \\
5 & $\mathrm{Rp} 67,416$ \\
10 & $\mathrm{Rp} 67,416$ \\
15 & $\mathrm{Rp} 67,416$ \\
\hline
\end{tabular}

HbA $_{1 \mathrm{C}}$ : Hemoglobin $\mathrm{A}_{1 \mathrm{C}}$

\section{CONCLUSION}

Treatment of patients with T2DM with counseling is more cost-effective compared to those without counseling. The result of this study should be considered by the policymakers to optimize the treatment of the patients with T2DM.

\section{REFERENCES}

1. World Health Organization. Global Report on Diabetes. Geneva: WHO Press; 2016. p. 6.

2. Depkes RI. Technical Guidelines for the Discovery and Management of Diabetes Melitus. Jakarta: Departemen Kesehatan RI; 2008. p. 1-3.

3. World Health Organization. Definition, Diagnosis and Classification of Diabetes Melitus and its Complications. Part 1: Diagnosis and Classification of Diabetes melitus. Department of Noncommunicable Disease Surveillance. Geneva: WHO; 1999.

4. Bustan MN. Epidemiology of Not Contagious Disease. Jakarta: Rineka Cipta; 2007.

5. Brown AF, Ettner SL, Piette J, Weinberger M, Shapiro MF,Karter AJ. Socioeconimic position and health among person with DM: A conceptual framework and review of the literature. Epidemiol Rev 2004;26:63-77.

6. Anna LK. Treatment of Diabetes Spend 33 Percent of Health Costs From BPJS. Avaialable from: http://www.health.kompas.com/ $\mathrm{read} / 2016 / 04 / 09 / 1500000023 /$ Pengobatan.Diabetes.Habiskan.33. Pesen.Biaya.Kesehatan.dari.BPJS. [Last accessed on 2017 Jan 24].

7. Sedyowinarso M, Fauziah FA, Aryakhiyati N, Julica MP, Munira L, Sulistyowati E. Perceptions and Readiness of Students and Lecturers of Health Professions to the Model of Learning Interprofesi Education: National Study of Students of Health Sciences Indonesia. Jakarta: Directorate General of Higher Education; 2011.

8. Depkes RI. Pharmaceutical Care for Diabetes Melitus. Jakarta: Departement Kesehatan RI; 2005. p. 62.

9. Depkes RI. Guidelines for Counseling of Pharmaceutical Services at Health Facilities. Jakarta: Departemen Kesehatan RI; 2007. p. 1-6.

10. Andayani TM. Cost analysis of diabetes melitus therapy at Dr.Sardjito hospital, Yogyakarta. Majalah Farm Indones 2006;17:130-5.

11. Drummond MF, O'Brien BJ, Stoddart GL, Torrance GW. Methods for the Economic Evaluation of Health Care Programmes. New York: Oxford University Press; 1997. p. 8, 139, 178.

12. Setyosari P. Research Methods of Education and Development. Jakarta: Prenada Media Group; 2010. p. 156.

13. Irawan D. Prevalence and Risk Factors for the Incidence of Type 2 Diabetes Melitus in Urban Indonesia (Secondary Data Analysis Riskesdas 2007). Tesis. Depok: Universitas Indonesia; 2010.

14. American Diabetes Association. Nutrition recommendations and inervention for diabetes. Diabetes Care J 2008;31:61-78.

15. Trisnawati S, Setyorogo S. Risk factors of diabetes melitus Type II incidence in a primary health center, Cengkareng, Jakarta Barat, 2012. J Ilmiah Kesehatan 2013;5:6-11.

16. Gibney MJ, Margetts BM, Kearney JM, Arab L. Public health nutrition. Jakarta: EGC; 2009.

17. Nasution A, Sulaiman SS, Shafie AA. Cost-effectiveness of clinical pharmacy education on infection management among patients with chronic kidney disease in an Indonesian hospital. Value Health Reg Issues 2013;2:43-7. 